\title{
Students' Perspectives on Future Employment: A Qualitative Study on Indonesian Higher Education Institutions during the COVID-19 Pandemic
}

\author{
Muhammad Haekal 1, Ahmad Arief Muttaqien 2, Ainal Fitri 3
}

DOI: $10.35445 /$ alishlah.v13i1. 502

\begin{abstract}
Article Info
Abstract

Keywords:

COVID-19

Educational leadership

Employment

Higher education

Undergraduate student

This study aims to determine how undergraduate students at Indonesian higher education institutions think about future jobs associated with aspects of the COVID-19 pandemic and the increase in precariat work. It involved twenty students from two public universities located in Aceh, Indonesia. Online in-depth interviews were used as the data collection methods. Additionally, Snyder's hope theory was utilised as a theoretical framework for this qualitative study. The theory would be useful in understanding the students' insights related to the precarity of the future job, especially in the aspect of goals, pathway, and agency. The study found that despite having a lack of visualisation towards the future, the undergraduate students generally believed that COVID-19 and precarious working arrangements were serious challenges towards future employment. Academic achievements such as high grades might not be sufficient unless supplemented by substantial organisational skills, vast networking, and a resilient entrepreneurial mentality. This study also underlined the vital role of higher education institutions in strategically preparing their students to face the unpredictability and precariousness of the future job marketplace.
\end{abstract}

Kata kunci:

COVID-19

Kepemimpinan

pendidikan

Pekerjaaan

Pendidikan tinggi

Mahasiswa sarjana

\begin{abstract}
Abstrak
Penelitian ini bertujuan untuk mengetahui bagaimana mahasiswa S-1 di institusi pendidikan tinggi Indonesia berpendapat mengenai pekerjaan di masa depan, dikaitkan dengan aspek pandemi COVID-19 dan meningkatnya pekerjaan prekariat. Studi ini melibatkan dua puluh mahasiswa dari dua perguruan tinggi negeri yang berlokasi di Aceh, Indonesia. Wawancara mendalam daring digunakan sebagai metode pengumpulan data. Selain itu, teori harapan Snyder digunakan sebagai kerangka teori pada penelitian kualitatif ini. Teori tersebut bermanfaat dalam memahami perspektif mahasiswa terhadap pekerjaan prekariat di masa depan, utamanya dalam aspek cita-cita, jalan, serta agensi. Studi ini menemukan bahwa meskipun memiliki visualisasi yang terbatas tentang pekerjaan di masa depan, para mahasiswa S-1 umumnya percaya bahwa COVID-19 dan prekariasi dunia kerja merupakan tantangan serius terhadap lapangan pekerjaan di masa depan. Prestasi akademis seperti nilai tinggi
\end{abstract}

\footnotetext{
${ }^{1}$ Universitas Islam Negeri Ar-Raniry, Banda Aceh, Indonesia

Email: muhammad.haekal@ar-raniry.ac.id

2 The University of Adelaide, Adelaide, Australia

Email: ahmadarief.muttaqien@student.adelaide.edu.au

3 Universitas Serambi Mekkah, Banda Aceh, Indonesia

Email: ainal.fitri@serambimekkah.ac.id
} 
mungkin tidak cukup kecuali dilengkapi dengan keterampilan organisasi yang kuat, jaringan luas, serta mentalitas kewirausahaan yang tangguh. Studi ini juga menggarisbawahi peran penting lembaga pendidikan tinggi dalam mempersiapkan siswanya secara strategis untuk menghadapi ketidakpastian dan gentingnya pasar kerja di masa depan.

\section{INTRODUCTION}

Unemployment has been a global issue, especially during the COVID-19 pandemic. International Labour Organisation projected that around 25 million people worldwide could lose their jobs during this pandemic (International Labour Organization, 2020). Without a decent job, people tend to have difficulties making their ends meet. This becomes a significant concern, and it needs critical planning and preparation to overcome the problems (Deady et al., 2020) . Besides battling with financial issues, unemployed people also face severe mental health problems, leading to suicidal behaviour (Brown \& Schuman, 2020; Kawohl \& Nordt, 2020; Milner, Page, \& LaMontagne, 2013) . This suicidal tendency has long been correlated with the economic downturn, specifically in the COVID 19 pandemic situation, creating the economic recession. However, the exact number of suicide rates caused by unemployment in this COVID 19 circumstances has not been fixed yet. Immediate and continuous preventive action is crucially required to avoid suicide attempts and other adverse psychological events (Deady et al., 2020) .

In the Indonesian context, the phenomena are likely occurring as well at the moment. Apart from affecting the health sector, COVID-19 has seemed to threaten many Indonesian industries, including trade, tourism, and transportation (Susilawati, Falefi, \& Purwoko, 2020) . The impact would drastically affect the power of the drives to operate normally. In consequence, they were forced to limit their operations by reducing the workers to survive this pandemic. Another harmful consequence of the pandemic would be the transformation of the working arrangements. The companies would prefer to hire employees on a contract basis rather than in a full-time contract.

Education institution worldwide is also affected by COVID-19. It transforms the learning process (Daniel, 2020) and exposes learning gaps, especially for those who live in difficult financial conditions (Van Lancker \& Parolin, 2020). Related to the career projection, internationally, students begin doubting their future professional career, and as a result, they can have mental health problem including anxiety and frustration (Aristovnik, Keržič, Ravšelj, Tomaževič, \& Umek, 2020) . In addition, a study in the United States found that COVID-19 has delayed 13\% of student's graduation, and $40 \%$ of them failed to get employment or internship (Aucejo, French, Araya, \& Zafar, 2020). Furthermore, the study above also indicated that poor students tend to experience more severe consequences than their peers who live under better socio-economic circumstances.

Globally, the higher institution has equipped students with the skill to enter the job market. A comparative study on Malaysian and Chinese students revealed that some universities provided valuable soft skills for their students' future employment, despite a factual finding that the quality differed from one institution to another (Teng, Ma, Pahlevansharif, \& Turner, 2019). Regarding the educational leadership and management aspect, a study underlined the significant position of the university in preparing its students to get a better outcome in job markets. One of the initiatives is providing its alumni with mentorship to boost their employability (Delaney, 2000). Another study highlighted the essential point of establishing a solid relationship between universities and their alumni. The alumni could provide volunteerism (like mentorship) and even political advocacy that could significantly impact the graduate profiles in the employability aspect (Weerts \& Ronca, 2007).

The intricate part of this pandemic is the inability to provide exact predictions on its end, and its impact on the unemployment rate in society as the circumstances tend to keep changing daily (Deady et al., 2020). When it links with other factors such as the socio-economic condition in a 
particular country, a strategic plan must be carefully designed to respond to its peril and adapt to complicated reality in any sectors affected by this pandemic.

Therefore, the significance of this study is to provide insights for universities regarding future job precarity (Standing, 2014) based on students' expectations and needs and the analysis of university's cultural aspects. In Indonesia, studies about universities' strategies towards future employment, precarious working arrangements, and the COVID-19 pandemic are infrequent, particularly those who position students' voices as the analysis centre. For instance, studies on the relationship between the universities' strategies and future employment can be seen from Asmawi's research (2010), emphasising the importance of increasing students, lecturers, facilities, and infrastructures. In addition, a study also confirmed that having a clear strategy for increasing students' competence would directly impact their entrepreneurial ability towards the future job marketplace (Astuti, 2019) . Another study indicated the significance of establishing networking between higher education institutions and industries to provide better outcomes for their alumni (Rofaida \& Gautama, 2019) . The studies mentioned above have not described the precarious working situation and the current pandemic, which significantly impact how the job markets operate during this challenging situation. Hence, this study would potentially fill the gap in discussing future works, precarious workers, and the pandemic.

Furthermore, this study attempted to answer at least three research questions. Firstly, this study would discover how undergraduate students in Indonesia reason this pandemic in future employment aspects. Secondly, it would analyse how the students prepare themselves for facing the job market. And lastly, this study would also discuss how educational leadership in Indonesian higher education institutions equips its students with future jobs precarity. The researchers expect the findings of this research can contribute to universities' strategical adaptation towards the precarity of future jobs during and post-COVID 19 pandemics. The researchers also believed the strategic planning of the future career would be urgently needed to decrease the percentage of educated unemployment in the country.

This study utilised Snyder's hope theory as the theoretical framework. Hope idea has three foundations: goals, pathway, and agency (Snyder, 2002). In a brief explanation, at the extreme level, people with a high hope relish the pursuit of goals and chase them with a positive mindset. If in one attempt they face failure, their high-hope trait enables them to bounce back, either to return with a stronger action or better strategy. On another side, people with low hope tend to position their mindset negatively since the beginning of their life goals pursuit. Consequently, it may also reflect their attitude and behaviour of doing activities and put them at a high risk of experiencing failure, together with depression and desperation. The researchers primarily used the hope theory to understand the students' insights related to the precarity of the future job.

\section{METHODS}

This research used the qualitative method with the expectations to obtain centred participants' perspectives about the phenomenon (Clark \& Creswell, 2014). In addition, the advantage of utilising the qualitative methodology is the ability for researchers to get deeper insights by investigating the respondents' attitude, perception, feeling, and understanding towards an issue (Rahman, 2020). This phenomenological research was conducted in two public universities in Aceh, Indonesia. During this pandemic, we used in-depth online interviews as the data collection method. Besides providing health protection during this pandemic, the online interview offered space for the respondents to supply more honest responses (Holge-Hazelton, 2002, as cited in Brinkmann, 2014). They had the option to be anonymous during the research.

Three research questions direct this study:

1. How do undergraduate students in Indonesia reason for this COVID-19 pandemic in the future employment aspect? 
2. How do students strategically prepare themselves to deal with the issue?

3. How is educational leadership in Indonesian higher education institutions equipping its students dealing with future jobs precarity?

The researchers conducted online in-depth interviews involving twenty research respondents to answer nine open-ended questions. Previously, all participants were asked to read one journal article and two news articles about precarious workers to better picture and understand the given issue. When it was required to do follow-up correspondents, the researchers asked participants to provide phone numbers or email addresses. The last process was to analyse and report the findings using a data analysis technique and the aforementioned theoretical frameworks. To support the data analysis, we utilised values coding suggested by Saldaña (2014), to analyse the participants' values, attitudes, and beliefs towards future jobs precarity. In this stage, the researchers created interview transcripts. Then, the researchers tried to find the value embedded within the respondents' beliefs and attitudes towards the discussed issues.

\section{FINDINGS AND DISCUSSION}

Briefly, it is found that despite having a lack of visualisation towards the future, the undergraduate students generally believed that COVID-19 and precarious working arrangements were serious challenges towards future employment. The students had various strategies to deal with their future careers. Additionally, the vital role of higher education institutions in strategically preparing their students to face the unpredictability and precariousness of the future job marketplace is also discussed in this section.

The students involved in this study were the first to seventh-semester students from two public universities in Aceh, Indonesia, from the Faculty of Education, Economics, and Engineering. 70\% of respondents were male, and 30\% of them were female students. All of the participants' study was funded by their parents. Meanwhile, in terms of family socio-economic condition, $45 \%$ of the participants were categorised as coming from lower-income family (under 3 million Rupiah/ month), 40\% were lower middle income ( 3 million to 5 million Rupiah/ month), and 15\% were upper middle income ( 5 million to 10 million Rupiah/ month).

\section{Undergraduate Students, COVID-19, and Future Precarious Employment}

$80 \%$ of the respondents selected their undergraduate courses themselves, while the other $20 \%$ considered parents' advice a consideration feature. In the future career aspect, almost all of the respondents believed that their selected courses would directly or indirectly relate to their future career choice. A Bachelor of Guidance and Counseling student, for instance, decided his degree because he had the aptitude and interest to become a school counsellor in the future. Similarly, students who were enrolled in a Bachelor of Economics program said they had either ambition to work in banking sectors or open their businesses. A study indicated that personal belief of skill competence or experience would connect to a person's career selection (Chuang, Goh, Stout, \& Dellmann-Jenkins, 2007). Another study related it more with personality type (Kemboi, Kindiki, \& Misigo, 2016).

Before getting involved in this study, 95\% of the respondents never heard about precariat as a concept. Standing (2014)mentioned that the precariat is a working condition in which workers work in a flexible working arrangement, such as part-timers, casual labourers, and other temporary positions. The escalation of precarious works emerges as the direct impact of neoliberalism, influencing the standard work model (Herod \& Lambert, 2016). As employment becomes flexible, the question regarding work stability also arises. A study later indicated that work stability itself directly linked with poverty (Filandri, Pasqua, \& Struffolino, 2020).

Some undergraduate students, especially the freshmen, experienced difficulty understanding the concept of precarious employment in the future and relating it to the COVID-19 pandemic. They expected that university was a direct gateway to occupation regardless of the current global socioeconomic condition. They hope everything would be fine after graduation, although Indonesia already faced a growing number of educated unemployed (Maryati, 2015) even before the pandemic. Additionally, their beliefs were also influenced by a religious concept in which they assured that every person would already have predestined fortune. 
On the other hand, the other students believed that future employment would be challenging and would need more struggles to enter the job markets. Despite the expected challenges, they thought that they must think about a solution to face jobs precarity in the future as young generations. One of the strategies they proposed was to develop the rate of entrepreneurship among fresh graduates. The strategy to face precarious working conditions, including its extreme result like unemployment, by growing entrepreneurship seems reasonable and supported by several academic studies (e.g., Onuma, 2016; Sondari, 2014). However, other studies also revealed that the connection between entrepreneurship and unemployment was nonlinear (Faria, Cuestas, \& Mourelle, 2010) . Another investigation found that innovation on a country's economic performance through entrepreneurship was indirect, particularly if the activity was self-performed by an unemployed person. The study asserted the power of entrepreneurship on unemployment would be seen when the entrepreneurial activity was on high-scale or massive-compared to the initiative to increase 'self-employment' (Audretsch, Carree, \& Thurik, 2001).

\section{Students' Strategy towards Future Precarious Employment}

From the in-depth interview results, generally, the participants showed hopeful perspectives towards future employment, regardless of their diverse reasons. Their hopes directly impact their optimistic projection towards a future career, and it can be seen through their practical ideas about the discussed issue. However, at this point, we must also forewarn the emergence of 'false hope' that can charge any egregious initiatives or adaptations.

In terms of facing the future unpredictable job market, $40 \%$ of the respondents believed that studying hard and getting an excellent high-Grade Point Average (GPA) would help them secure an occupation, regardless of the previous factual finding of the rise of educated unemployment in Indonesia.

On the other hand, $30 \%$ of the respondents believed that to survive in the future job market, they must create and maintain vast networking with employers or key people who could help them professionally with their experience in the workplace. Also, before graduation, they believed that getting involved in extracurricular activities, like joining internal organisations or clubs in their universities, would also escalate their skills before running a career in the company. In this sense, they were confident that networking inside or outside the universities would increase their acceptability in the job market. It could boost other attributes, such as a GPA.

Apart from other responses, an affluent socio-economic condition could create a more confident stance towards the future job market. For instance, a 19 years old Faculty of Education student said he was more relaxed as he owned a palm oil plantation. Despite studying for an English education (student-teacher) degree, he would picture his career as a businessman. He would use English to support him in managing the plantation, and he also predicted to establish a relationship with a foreign business company. As an individual, he had a substantial social capital which enabled him to get benefits and opportunities from strong familial and networking relationships (Bourdieu, 1986, as cited in Reavis, 2018) . Reflected on his case, we argue that the issue of future employment at an individual level cannot be separated from a person's socioeconomic status.

\section{The Role of Educational Leadership on Preparing Students towards Future Jobs Precarity}

Concerning universities' preparation, $60 \%$ of the respondents, especially the freshmen, could not determine whether their institutions had provided strategy for them towards future jobs precarity. As new students, they just began studying and had not understood much about the institutions. On the other side, some respondents believed that the universities had already equipped students with education and skills without explaining how it could benefit them in facing future jobs. Further, all of the participants suggested the universities add more initiatives to prepare them to face job precarity, including underpinning the internship program, designing a practice-based curriculum, establishing a vacancy information system, and introducing entrepreneurialism. Besides that, some respondents explained about 'civil-servant mentality' that was deeply engrained among youth generations. Civil-servant is a continuous and lifetime public employment designed by the Indonesian government. This image could be a mental block for the youths to be flexible in the job market, and it might trap them into long-term unemployment that contained the risk of social exclusion (Kieselbach, 2003).

During the age of uncertainty like this pandemic, the researchers believe that every institution, including higher education, needs transformational leadership. According to Podsakoff, MacKenzie, 
and Bommer (1996), to achieve transformational leadership level, leaders must communicate vision, supply a suitable model, maintain the acceptance of the group goals, have a high-performance expectation, create individualised support, and establish intellectual stimulation. Also, regarding the future of employment, leaders must have the visioning characteristic that enables them to produce an enthralling vision about the future (Ancona, 2005). Therefore, they could predict future employment and design strategic initiatives to help their students and alumni thrive during this uncertain time. A study also argued that having leadership who had future orientation could help an institution survive difficult situations (Gurr \& Drysdale, 2020). It is also essential for leaders to have an adaptive stance (Dunn, 2020): a continuous activity to experiment with tactical initiative and a willingness to navigate to other strategies if one is not working. Last but not least, above all, leaders must have a strong sense of empathy and humanity (Tran, Hardie, \& Cunningham, 2020) that could be an ideological foundation for their leadership action.

\section{CONCLUSION}

It is difficult to deny that the COVID-19 pandemic has brought tremendous challenges to the global economic condition. Therefore, future job seekers must be willing to prepare for a lengthy job search and create valuable networking and support from others during post-COVID 19 pandemics. On another side, higher education institutions must understand that their role is essential in preparing their students to face the unpredictable future.

This study has answered how the undergraduate students in Indonesia perceived the future employment challenges during the COVID-19 pandemic and the escalation trend of the precarious working conditions. In addition, this study has highlighted the students' strategies for facing future employment challenges. Lastly, this study also discussed the role of higher education institutions in preparing their students to face the future job marketplace. The limitation of this study is the involvement of the leadership and management figures of higher education and industries. Hence, it would be an opportunity to study further the insights of higher education and industries concerning the strategy against the acceptability of university graduates in the job markets.

In summary, the undergraduate students in Indonesia perceived this pandemic as challenging regarding future employment aspects. They remained hopeful to survive during this pandemic, regardless of their diverse argumentations. In the preparation aspect, they believed that academic achievement, organisational experience, networking, and entrepreneurial mindset would be essential as the core strategy to thrive during this pandemic. On the other hand, the role of educational leadership would become more vital in preparing their students and alumni to succeed in their desired careers. The researchers argue that having a solid adaptive mindset could be the first foundational mentality to deal with this issue.

\section{REFERENCES}

Ancona, D. (2005). Leadership in an Age of Uncertainty. Center for Business Research Brief, 6(1), $1-3$.

Aristovnik, A., Keržič, D., Ravšelj, D., Tomaževič, N., \& Umek, L. (2020). Impacts of the COVID-19 pandemic on life of higher education students: A global perspective. Sustainability, 12(20), 8438.

Asmawi, M. R. (2010). Strategi meningkatkan lulusan bermutu di perguruan tinggi. Hubs-Asia, 1O(1). https://doi.org/10.7454/mssh.v9i2.124

Astuti, E. D. (2019). Kompetensi Lulusan Perguruan Tinggi Vokasi Dalam Strategi Mewujudkan Sumberdaya Yang Berwawasan Entrepreneur. Abiwara: Jurnal Vokasi Administrasi Bisnis, 1(1), 1-7. https://doi.org/10.31334/abiwara.v1i1.496

Aucejo, E. M., French, J., Araya, M. P. U., \& Zafar, B. (2020). The impact of COVID-19 on student experiences and expectations: Evidence from a survey. Journal of Public Economics, 191, 104271.

Audretsch, D. B., Carree, M. A., \& Thurik, A. R. (2001). Does entrepreneurship reduce unemployment? Tinbergen Institute discussion paper. 
Brinkmann, S. (2014). Unstructured and semi-structured. In P. Leavy (Ed.), The Oxford handbook of qualitative research (pp. 277-299). New York: Oxford University Press, USA.

Brown, S., \& Schuman, D. L. (2020). Suicide in the time of COVID- 19: A perfect storm. The Journal of Rural Health.

Chuang, N.-K., Goh, B. K., Stout, B. L., \& Dellmann-Jenkins, M. (2007). Hospitality undergraduate students' career choices and factors influencing commitment to the profession. Journal of Hospitality \& Tourism Education, 19(4), 28-37.

Clark, V. L. P., \& Creswell, J. W. (2014). Understanding research: A consumer's guide (2nd ed.). Pearson Higher Ed.

Daniel, J. (2020). Education and the COVID-19 pandemic. Prospects, 49(1), 91-96.

Deady, M., Tan, L., Kugenthiran, N., Collins, D., Christensen, H., \& Harvey, S. B. (2020). Unemployment, suicide and COVID-19: using the evidence to plan for prevention. Medical Journal of Australia.

Delaney, A. M. (2000). Voices of experience: renewing higher education with alumni studies. Tertiary Education and Management, 6(2), 137-156.

Dunn, R. (2020). Adaptive Leadership: Leading Through Complexity. CCEAM, 31.

Faria, J. R., Cuestas, J. C., \& Mourelle, E. (2010). Entrepreneurship and unemployment: a nonlinear bidirectional causality? Economic Modelling, 27(5), 1282-1291.

Filandri, M., Pasqua, S., \& Struffolino, E. (2020). Being working poor or feeling working poor? The role of work intensity and job stability for subjective poverty. Social Indicators Research, 147(3), 781-803.

Gurr, D., \& Drysdale, L. (2020). Leadership for challenging times. International Studies in Educational Administration, 48(1), 24-30.

Herod, A., \& Lambert, R. (2016). Neoliberalism, precarious work and remaking the geography of global capitalism. In R. Lambert \& A. Herod (Eds.), Neoliberal capitalism and precarious work (pp. 1-35). Edward Elgar Publishing.

International Labour Organization. (2020, March 18). Almost 25 million jobs could be lost worldwide as a result of COVID-19, says ILO [Press release]. Retrieved February 8, 2021, from International Labour Organization website: https://www.ilo.org/global/about-theilo/newsroom/news/WCMS_738742/lang--en/index.htm

Kawohl, W., \& Nordt, C. (2020). COVID-19, unemployment, and suicide. The Lancet Psychiatry, $7(5), 389-390$.

Kemboi, R. J. K., Kindiki, N., \& Misigo, B. (2016). Relationship between personality types and career choices of undergraduate students: A case of Moi University, Kenya. Journal of Education and Practice, 7(3), 102-112.

Kieselbach, T. (2003). Long- term unemployment among young people: The risk of social exclusion. American Journal of Community Psychology, 32(1-2), 69-76.

Maryati, S. (2015). Dinamika pengangguran terdidik: tantangan menuju bonus demografi di Indonesia. Economica: Jurnal Program Studi Pendidikan Ekonomi STKIP PGRI Sumatera Barat, 3(2), 124-136.

Milner, A., Page, A., \& LaMontagne, A. D. (2013). Long-term unemployment and suicide: a systematic review and meta-analysis. PloS One, 8(1), e51333.

Onuma, N. (2016). Entrepreneurship education in Nigerian tertiary institutions: A remedy to graduates unemployment. British Journal of Education, 4(5), 16-28.

Podsakoff, P. M., MacKenzie, S. B., \& Bommer, W. H. (1996). Transformational Leader Behaviors and Substitutes for Leadership as Determinants of Employee Satisfaction, Commitment, Trust, and Organizational Citizenship Behaviors. Journal of Management, 22(2), 259-298. https://doi.org/10.1177/014920639602200204 
Rahman, M. S. (2020). The advantages and disadvantages of using qualitative and quantitative approaches and methods in language "testing and assessment" research: A literature review. Journal of Education and Learning, 6(1), 102-102. https://doi.org/10.5539/jel.v6n1p102

Reavis, T. B. (2018). Illuminating systemic inequality in education: Using Bourdieu in critical qualitative data analysis. In R. Winkle-Wagner, J. Lee-Johnson, \& A. N. Gaskew (Eds.), Critical Theory and Qualitative Data Analysis in Education (pp. 81-91). New York, NY: Routledge.

Rofaida, R., \& Gautama, B. P. (2019). Strategi Peningkatan Kompetensi Lulusan Perguruan Tinggi melalui Studi Pelacakan Alumni (Tracer Study). Image: Jurnal Riset Manajemen, 8(1), 1-8. https://doi.org/10.17509/image.v7i1.23171

Saldaña, J. (2014). Coding and analysis strategies. In P. Leavy (Ed.), The Oxford handbook of qualitative research (pp. 581-605). New York, NY: Oxford University Press.

Snyder, C. R. (2002). Hope theory: Rainbows in the mind. Psychological Inquiry, 13(4), 249-275.

Sondari, M. C. (2014). Is entrepreneurship education really needed?: Examining the antecedent of entrepreneurial career intention. Procedia-Social and Behavioral Sciences, 115, 44-53.

Standing, G. (2014). The Precariat. Contexts, 13(4), $10-12$. https://doi.org/10.1177/1536504214558209

Susilawati, S., Falefi, R., \& Purwoko, A. (2020). Impact of COVID-19's Pandemic on the Economy of Indonesia. Budapest International Research and Critics Institute (BIRCI-Journal): Humanities and Social Sciences, 3(2), 1147-1156.

Teng, W., Ma, C., Pahlevansharif, S., \& Turner, J. J. (2019). Graduate readiness for the employment market of the 4th industrial revolution. Education+ Training.

Tran, H., Hardie, S., \& Cunningham, K. M. W. (2020). Leading With Empathy and Humanity: Why Talent-Centred Education Leadership is Especially Critical Amidst the Pandemic Crisis. International Studies in Educational Administration (Commonwealth Council for Educational Administration \& Management (CCEAM)), 48(1), 39-45.

Van Lancker, W., \& Parolin, Z. (2020). COVID-19, school closures, and child poverty: a social crisis in the making. The Lancet Public Health, 5(5), e243-e244.

Weerts, D. J., \& Ronca, J. M. (2007). Profiles of supportive alumni: Donors, volunteers, and those who “do it all." International Journal of Educational Advancement, 7(1), 20-34. 